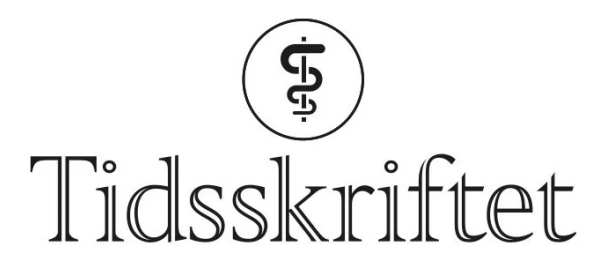

DEN NORSKE LEGEFORENING

\title{
Indre monolog som arbeidsmetode
}

\author{
LEGELIVET
}

\section{ALEXANDER WAHL}

alexanderwahl32@gmail.com

Alexander Wahl er spesialist i allmennmedisin, veileder, arbeider på Kurbadet legesenter og er redaktør for primærhelsetjenesten i Helsebiblioteket, Folkehelseinstituttet.

\section{I undervisning og tidsskrifter brukes kasuistikken ofte som et pedagogisk grep. Kasuistikkene er ofte knappe og saklige, men de kan formidles på annet vis. Her kommer mitt forslag til indre monolog som en videreutvikling av kasuistikken som arbeidsmetode.}

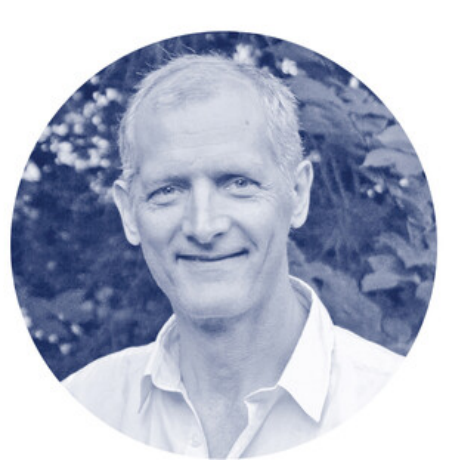

Foto: privat

Indre monolog eller stream of consciousness er et litterært begrep som beskriver en narrativ metode der man forsøker å fange opp et bredt spekter av tanker og følelser som strømmer gjennom fortellerens sinn. Ofte er vi lite oppmerksomme på de indre samtalene vi har i oss, selv om de er med på å utgjøre grunnlaget for beslutninger. Men innen kognitiv psykologi er tankeprosesser og tankemønstre svært sentrale for å forstå hva som foregår.

Tankene kan avsløre følelsesmessige utfordringer, dilemmaer og faglige kortslutninger. Klinisk arbeid i allmennpraksis skjer under tidspress og usikkerhet. Dersom legen skriver ned et referat fra en vanskelig konsultasjon, kan referatet også inneholde egne tanker og refleksjoner under konsultasjonen. For at referatet skal bli mest mulig autentisk, bør man skrive det ned så raskt og så utførlig som mulig.

Nedenfor beskriver jeg en kasuistikk med pasienttillatelse fra allmennpraksis.

Anamneseopptak og handlingsforløp er utvidet med legens løpende refleksjoner. For hvert avsnitt har jeg foreslått et tema for diskusjon i vår smågruppe. 
Jeg er noe forsinket, og da blir jeg litt mer effektiv, litt knappere og litt mindre hjertelig. Pasienten er en kvinne i 20 -årene. Dagen før hadde hun vart på dans, men etter dansen ble hun svimmel (ja, alle kan vel bli svimle) og fikk dotter $i$ synsfeltet (det var da rart, overdriver hun?).

Tema: Hvordan vurderer vi pasienter om de er nøkterne, overdriver eller bagatelliserer?

«Fikk du vondt $i$ hodet etterpå?» spør jeg og tester ut hypotesen om migrene med aura.

"Nei, ikke vondt $i$ hodet - men hun ble litt rar i nakken på venstre side».

(Rar i nakken, jeg kan ikke skrive rar i nakken i journalen - hva er det hun mener med rar i nakken, og hva er disse dottene mon tro?)

Tema: Hvordan kan vi hjelpe pasienten til å uttrykke seg mer presist?

«Bruker du p-piller?» spør jeg. «Nei, det gjorde hun ikke. Men det var én ting til - hun hadde vansker med å heve høyre arm over hodet etterpå».

(Uff, dette var en uvanlig opplysning. Kan det vere en nevrologisk sykdom? Jeg har aldri hatt en så ung dame med slike symptomer før. Damen ser frisk og livlig ut, og hun fortjener å vcere frisk. Jeg har lyst til at hun skal vere frisk. Jeg er opprørt, men ønsker aller helst å berolige, underslå opplysninger, bagatellisere. Men nå føler jeg meg tvunget til en nevrologisk undersøkelse. Og det har jeg $\underline{i k k e}$ lyst til. Det er tidkrevende, og jeg husker ikke alle hjernenervene. Bør jeg egentlig teste alle? Og egentlig føler jeg meg litt matt og har vondt i magen og må på do.Jeg har ikke tid til å gå på do.)

Tema: Kan noen i gruppen demonstrere orienterende nevrologisk undersøkelse $i$ allmennpraksis?

Orienterende nevrologisk undersøkelse avdekker en litt svak patellarefleks på venstre side (eller er den mer livlig på den høyre?), ellers uten anmerkning. Dette var lite håndfast.Jeg setter meg ned og skriver. Notatet må formuleres og ortografien korrigeres, mens jeg veier for og imot hva neste tiltak må vcere. Forsinkelsen i timeboken har økt på, og jeg ncermer meg en avgjørelse. En avgjørelse som kan innebcre overutredning og ressurssløsing, eller? Det er ikke populcrt med unødvendige innleggelser. Men nei,jeg føler at pasienten er troverdig, jeg må stole på pasientens fremstilling, selv om det høres rart ut. Hun kommer utenbys fra, kanskje har hun et lite nettverk her, foreldrene er sikkert engstelige, hun er mitt ansvar. Jeg bestemmer meg for å søke råd hos nevrolog. Men før det må jeg formulere meg skånsomt overfor pasienten, ymte frempå at symptomene er uvanlige, at jeg ønsker å ta henne på alvor og at jeg nå vil søke råd hos en spesialist.Jeg må ikke virke altfor bekymret - jeg skal ikke påføre pasienten unødvendig angst.

Tema: Legen balanserer mellom plikten til å informere versus frykten for å skremme unødig - refleksjoner i gruppen?

Nevrologen ber meg ringe slagavdelingen, og klokken tikker videre. Telefonlinjer veksles og jeg kobles til slutt på legen som skal si ja eller nei. Heldigvis tar de pasienten inn.Jeg er lettet,

utredningsansvaret er herved overtatt av et sykehusteam. Pasienten tar det pent, gråter ikke, trenger ikke trøst.Jeg tenker på henne sporadisk de ncermeste dagene. Epikrisen kommer en tid senere med en diagnose som er ny for min praksis og som ikke sto på innleggelsesskrivet mitt: carotisdisseksjon. Tema: Refleksjoner rundt sjeldne diagnoser i allmennpraksis.

Tradisjonelt har kasuistikker i gruppearbeid/veiledning oftest vært svært knappe og saklige og mest fokusert på mulige differensialdiagnoser og tiltak for utredning, uten beskrivelse av ambivalens og emosjonelt virvar hos legen. Når vi tar med beskrivelsen av

følelsesmessige reaksjoner i vårt arbeid, blir vi bedre kjent med oss selv. Følelser kan både styrke legearbeidet og intuisjonen, mens andre ganger kan det forblinde og undertrykke logisk deduksjon. Det siste er det også viktig å være seg bevisst.

Gjennomgang av kasuistikken avdekker legens emosjonelle reaksjoner og dilemmaer ved tolkning av pasientutsagn, journalføring og undersøkelser. I en trygg (veilednings)gruppe med god ledelse eller i en veiledningssamtale med en-til-en-veileder kan denne ærlige arbeidsmåten, avsnitt for avsnitt, fremme gjenkjennelse og faglig vekst. I vår gruppe vant disse umiddelbare reaksjonene gjenklang hos de andre deltakerne, og det førte til spennende diskusjoner med nye innfallsvinkler.

Lykke til, til den som tør.

Pasienten har gitt samtykke til at artikkelen blir publisert. 
Publisert: 8. november 2021. Tidsskr Nor Legeforen. DOI:10.4045/tidsskr.21.0674

(C) Tidsskrift for Den norske legeforening 2023. Lastet ned fra tidsskriftet.no 26. april 2023. 